\title{
Energy Cost of Feeding in Rocky Mountain Bighorn Sheep
}

\author{
R. W. CHAPPEL \& R. J. HUDSON
}

Chappel R. W. \& Hudson R. J., 1978: Energy cost of feeding in Rocky Mountain bighorn sheep. Acta theriol., 23, 21: 359-363 [With 1 Table \& 1 Fig.]

The energy cost of eating alfalfa/brome hay was determined for four Rocky Mountain bighorn sheep. The average increase in metabolic rate was 0.43 and $0.46 \mathrm{kcal} . \mathrm{kg}^{-1} \cdot \mathrm{h}^{-1}$ for ewes and rams, respectively. This represented an increment of approximately $32 \%$. Although the energy cost of eating was less than that of domestic sheep, it appeared to represent an important component of the energy budget of free-ranging animals.

[Dept. Anim. Sci., Univ. Alberta, Edmonton, Canada T6G E3].

\section{INTRODUCTION}

The energy requirement of free-ranging wild ruminants usually is estimated to be in the order of 2 to 3 times festing metabolism. The increment of free existence is considered to include the energy costs of locomotion and thermoregulation and the heat increment of feeding. The heat increment of feeding has been taken to be a function only of the quantity and quality of food ingested while the energy expenditure associated with grazing until quite recently was considered to be negligible. However, O s u j i (1974) reviewed available information and concluded that it made a considerable contribution to the daily energy budget of ruminants at pasture, primarily because such a large proportion of the day is spent engaged in this activity. This study was conducted to determine the energy costs of feeding in a North American wild ruminant, the Rocky Mountain bighorn sheep (Ovis canadensis).

\section{METHODS}

Four captive adult Rocky Mountain bighorn sheep, two ewes and two rams, were available for this study. They were trained over a period of eight months to stand, with a minimum of excitement, in metabolic crates. Respiratory gases were collected in a ventilated hood surrounding feeding buckets and analyzed using an open circuit respiratory pattern analyzer ( $\mathrm{Y}$ o ung et. al., 1975). Oxygen consumption and carbon dioxide production was translated to energy expenditure using the equation of Brou wer (1965). 
The animals were fasted for 72 hours prior to each trial. Metabolic rate was measured at 10 minute intervals before, during and after feeding on a ration of long hay comprised of alfalfa and brome grass. A total of four trials were conducted.

\section{RESULTS AND DISCUSSION}

The experimental animals consumed their ration of long hay over a period of about forty minutes. Metabolic rates before, during and after the feeding bout are shown in Fig. 1. Various modes of expression of the costs of eating are given in Table 1.

Energy expenditure increased significantly $(\mathrm{P}<0.05)$ during the act of eating and declined slowly once eating had ceased. The mean increment was not significantly different between ewes and rams, although fasting
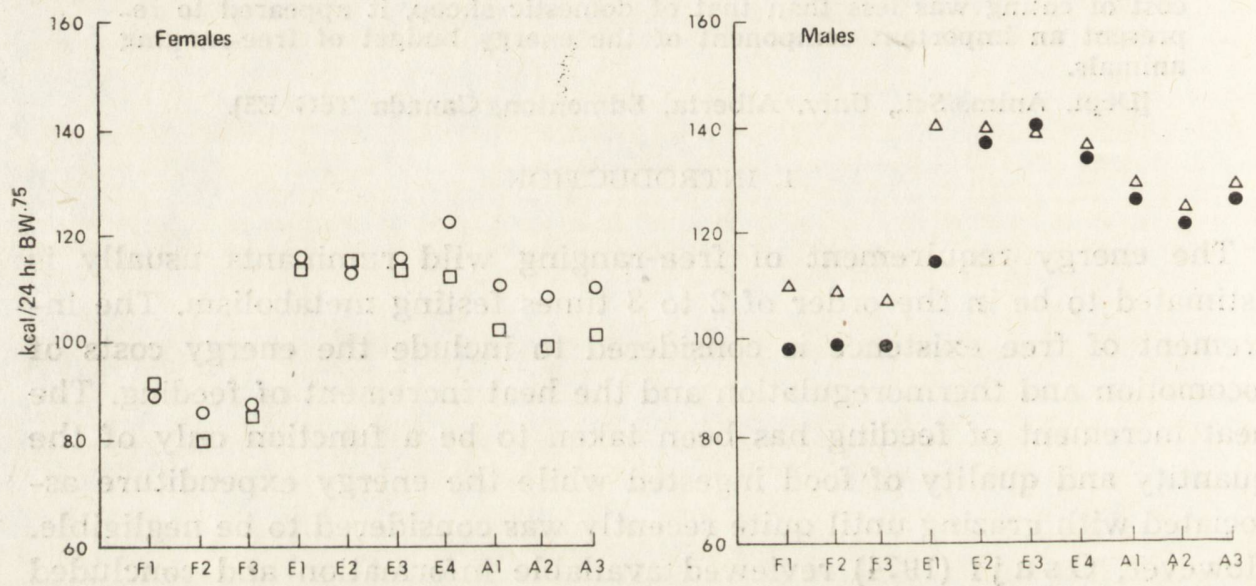

Fig. 1. Energy expenditures before, during and after eating alfalfa-brome hay. $\mathrm{F} 1-\mathrm{F} 3$, fasting metabolic rate in $30 \mathrm{~min}$. intervals; E1-E4, metabolic rate during eating in $10 \mathrm{~min}$. intervals; $\mathrm{A} 1-\mathrm{A} 3$, metabolic rate after eating in $30 \mathrm{~min}$. intervals.

and fed metabolic rates were consistently higher in the rams. The average percentage increase in metabolic rate as a result of the act of eating was $33.4 \%$ for ewes and $31.0 \%$ for rams.

The energy costs of eating appears to be more a function of the time spent eating than of the type or the weight of material ingested $(\mathrm{Os} \mathrm{u} \mathrm{ji}$ et al., 1975). Expressed in these terms, the energy increment due to feeding measured in Rocky Mountain bighorn sheep was lower than most values reported for domestic sheep. G r a h a m (1964) found an increase of $0.54 \mathrm{kcal} \cdot \mathrm{kg}^{-1} \cdot \mathrm{h}^{-1}$ for cut dried hay whereas bighorn sheep used in 
this study increased their expenditure in the order of 0.43 to $0.46 \mathrm{kcal}$. $\mathrm{kg}^{-1} \cdot \mathrm{h}^{-1}$ while consuming cut alfalfa-brome hay. W e bs ter \& $\mathrm{H}$ a y s (1968) in the same laboratory measured an energy increment of 0.83 $\mathrm{kcal} \cdot \mathrm{kg}^{-1} \cdot \mathrm{h}^{-1}$ for domestic sheep eating the same type of hay. B l a x t e r \& J oy ce (1963) and Christopherson \& W ebster (1972) noted increases of 50 to $60 \%$ whereas in these trials the animals elevated their metabolic rates by only $32 \%$.

The discrepancy between the energy costs of eating in bighorn and domestic sheep is not easily explained. Rates of consumption of bighorn sheep were from 675 to 825 g.h ${ }^{-1}$ for ewes and rams, respectively, which is comparable to rates of feeding in domestic sheep. However, subjectively, the animals seemed to display less excitement than domestic sheep following similar fasts.

Table 1

Metabolic rates of bighorn sheep prior to and during eating ( \pm S.E.).

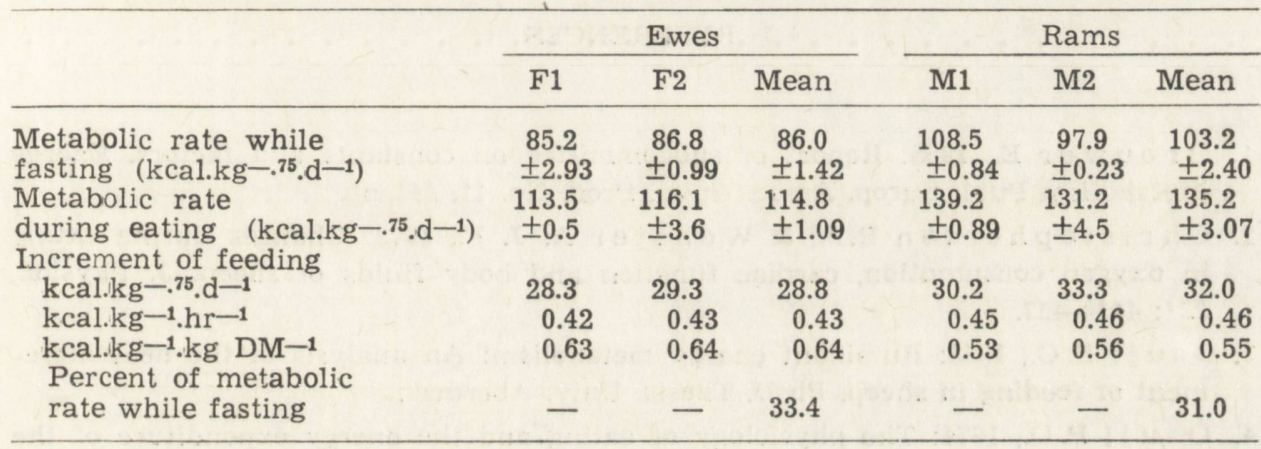

The heat increment of feeding is a measure of all thermogenic consequences of eating without reference to their physiological origin (W e bst e r, 1972). Generally, it is thought to include the energy cost of prehension and mastication, heat produced during fermentation of feed by rumen micro-organisms, the work of digestion by the gut and the energy cost of metabolizing the major end-products of fermentation.

Young (1966) attributed the initial rapid rise in the metabolic rate of domestic sheep when food was given to psychic factors and to the act of prehension and mastication. Using sheep fitted with oesophageal fistulae, he demonstrated that the presence of food in the rumen made a negligible contribution to this initial rise.

Metabolic rate remains somewhat elevated following the act of eating. In this study metabolic rate declined only slowly following the cessation of feeding. Osuji (1973) found that visceral heat increment due to aerobic gut metabolism in domestic sheep accounted for about $66 \%$ of 
the increased heat production of the viscera drained by the portal vein. This suggests that there is an appreciable work of digestion over and above the heat generated by microbial degradation of ingesta.

This study did not examine the relative costs of eating forages of different physical form. However, trials by $\mathrm{Osuji}$ (1973) suggest that forage type is important mainly as it effects the rate of food intake and the time spent grazing.

Since the energy cost of eating varies directly with the time spent eating, animals on range would expend considerably more energy foraging than animals fed indoors. W e bste $r$ (1972) calculated that domestic animals grazing for 8 hours a day would add $25-50 \%$ to their maintenance energy requirement. The increment for bighorn sheep would appear to be somewhat less. Nevertheless, the energy cost of feeding remains an important component of their daily energy budget.

\section{REFERENCES}

1. Brouwer E., 1965: Report of subcommittee on constants and factors. Energy Metabolism Publ. Europ. Assoc. Anim. Prod. No. 11. 441 pp.

2. Christophers on R. J., \& W e bster A. J. F., 1972: Changes during eating in oxygen consumption, cardiac function and body fluids of sheep. J. Physiol., 221: $441-457$.

3. Os uji P. O., 1973: Ruminant energy metabolism: An analysis of the heat increment of feeding in sheep. $\mathrm{Ph} \mathrm{D}$. Thesis. Univ. Aberdeen.

4. Osuji P. O., 1974: The physiology of eating and the energy expenditure of the ruminant at pasture. J. Range Manage., 27: 437-443.

5. Osuji P. O., Gordon J. G. \& Webster A.J.F., 1975: Energy exchanges associated with eating and rumination in sheep given grass diets of different physical forms. Br. J. Nutr., 34: 59-71.

6. We bster A.J.F., 1972: Act of eating and its relation to the heat increment of feed in ruminants. In: Bioenergetics International Symposium on Environmental Physiology. Amer. Soc. Exp. Biol., 42-48.

7. Young B. A., 1966: Energy expenditure and respiratory activity of sheep during feeding. Austr. J. Agric. Res., 17: 355-362.

8. Young B. A., Kerrigan B. \& Christopherson R. J., 1975: A versatile respiratory pattern analyzer for studies of energy metabolism of livestock. Can. J. Anim. Sci., 55: 17-22.

Accepted, April 5, 1978. 
R. W. CHAPPEL i R. J. HUDSON

\section{ENERGETYCZNY KOSZT ZYWIENIA SIE U OWCY KANADYJSKIEJ}

\section{Streszczenie}

Zbadano energetyczny koszt odżywiania się u czterech owiec kanadyjskich (Ovis canadensis) karmionych sianem. W porównaniu z metabolizmem spoczynkowym wydatki energetyczne zużywane na jedzenie wzrastają średnio o $32 \%$ co stanowi $0.43 \mathrm{kcal} . \mathrm{kg}^{-1} \cdot \mathrm{h}^{-1}$ dla owiec i $0.46 \mathrm{kcal} . \mathrm{kg}^{-1} \cdot \mathrm{h}^{-1}$ dla baranów (Tabela 1, Ryc. 1). Chociaż energetyczny koszt jedzenia $u$ owiec kanadyjskich jest prawie dwukrotnie niższy niż u owiec domowych jest on ważnym składnikiem budżetu energetycznego zwierząt wolnożyjących. 